\title{
Relationship Good Governance with Welfare Society Mediated by Local Government Financial Disclosure and Audit Report Opinion (Study on Local Government South Southeast Sulawesi)
}

\author{
Mulyati Akib" , Abdul Hamid Habbe ${ }^{2}$, Yohanis Rura ${ }^{3}$, Adnan Hakim ${ }^{4}$ \\ ${ }^{1,4}$ Lecturer, Faculty of Economics and Business University Halu Oleo, 93711, Sulawesi Tenggara Indonesia \\ ${ }^{2,3}$ Lecturer, Faculty of Economics and Business University of Hasanuddin, Sulawesi Selatan Indoensia
}

\begin{abstract}
This research to: 1) identify and explain the influence of good governance to the welfare of society with indicators GDP, public consumption and HDI; 2) identify and explain the influence of good governance to the welfare of society through disclosure financial statement local government, and audit report opinion. This research uses secondary data with the 37 local government consisting of first local government of South Sulawesi with 24 cities/districts and first local governments Southeast Sulawesi with 12 cities/districts using census method. The data were tabulated and yielded negative results were excluded from the sample so that the data is processed by 170 samples. Testing is done with the purpose of data variables $t+2$. The data were analyzed using path analysis. The results showed that: 1) Good Governance affect welfare society with consumption indicators and HDI; 2) Good Governance affect welfare society with private consumption and HDI indicators through audit report but Good Governance has no effect on welfare society through disclosure Financial Statement Local Government; Good Governance has no effect on welfare society with the GDP indicator through audit report.
\end{abstract}

Keyword: Good Governance, Financial Statement Local Government, Audit Report, Welfare Society.

\section{Background Research}

Public welfare from the perspective of financial management areas, can be achieved when applying Good Governance (GG) (UNDP, 2000). Conceptualization of good governance is more emphasis on the realization of democracy, because it is a democratic state organization becomes absolutely necessary for the realization of good governance, which is based on the accountability, transparency, and public participation. Ideally, those three things will be present in each institutional actor is the attention to human values and moral values that permeate every step of governance. (Krina, BAPENAS).

Regional autonomy is the right, authority, and obligation autonomous regions to organize and manage their own affairs and interests of local communities in accordance with the legislation (Law 32/2004). Regional government held government affairs under its authority, which is the overflow of the central government to the regions. Nonetheless, government affairs such as foreign policy, defense, security, monetary and national fiscal central government still regulated (Mardiasmo, 2002).

Government Regulation No. 60 of 2007 describes the financial statements are prepared to provide relevant information regarding the financial position and all transactions are carried out by a reporting entity during the reporting period. The financial statements are primarily used to determine the economic value of the resources used to carry out the operations of government, assess the financial condition, evaluating the effectiveness and efficiency of a reporting entity, and helps determine adherence to laws and regulations. Reporting entity has an obligation to report on the efforts that have been made and the results achieved in the implementation of activities in a systematic and structured in a reporting period for parties who require such financial statements.

Government financial reports should provide information useful to the users of financial statements. The quality of the financial statements show a true and honest information. Qualitative characteristics are the traits that make information in financial statements useful to users. principal qualitative characteristics ie, comprehensible, relevant, and comparable reliability (SFAS No. 1). Local governments in assessing accountability and making good decisions economic, social, political and financial statements must refer to the local government. The financial statements of the local government aims to: a) provide information about the sources, allocation and use of financial resources; b) provide information on the adequacy of the acceptance period to cover all the expenses; c) provide information on the amount of economic resources that are used in the activities of the reporting entity and the results that have been achieved; d) provide information on how the reporting entity to fund its operations and meet its cash needs; e) provide information about the financial position and condition of the reporting entity associated with the sources of revenues, both short and long term, including those derived from taxation and borrowing. f) provide information regarding changes in the financial position of the reporting entity, whether an increase 


\section{International Journal of Science and Research (IJSR) \\ ISSN (Online): 2319-7064}

Index Copernicus Value (2013): 6.14 | Impact Factor (2014): 5.611

or decrease, as a result of activities undertaken during the reporting period.

Law No.. 17 of 2003 on State Finance set among other areas of financial management and accountability. These settings include the preparation of the Regional Budget (budget) performance-based and comprehensive financial reports as a form of accountability that must be examined by the State Audit Agency (Mardiasmo, 2002). Article 23 UUD 1945 also stipulates that the state is obliged to submit financial liability immediately after the fiscal year ends, and will be the basis of the examination by the SAA. The article suggests that there is a government obligation to prepare the state's financial accountability. The statement also applies to local governments. Local governments also have a duty to make the local financial accountability of local government financial reports.

Article 101 of the law no. 32 explains that the local government financial reports submitted to the Audit report no later than three (3) months after the fiscal year ends. The State Audit Agency (SAA) is a high institution which holds the state constitutional mandate to inspect or audit the financial management responsibilities of the State. SAA as a government auditor, won the trust to examine the financial statements presented by the client, namely local government. Presentation of financial statements is one form of implementation of the accountability of public financial management.

The orientation of the public sector development is intended to achieve good governance (Mardiasmo, 2002). According to UNDP (2000) gives some of the characteristics of good governance, including transparency, responsiveness, consensus orientation, equity, efficiency and effectiveness, and accountability. From these characteristics, there are at least three things that can be played by the public sector accounting namely transparency, value for money, and accountability. In providing services to the public, local governments are required faster and more responsive or responsive.

There are three (3) regional mechanisms that can be implemented to make it more responsive, transparent, and accountable and can further realize good governance, namely: (1) listening to the voice or the aspirations of the community and to build a community development cooperation, (2) improve the internal rules and control mechanisms, and (3) establish a climate of competition in providing services to the community and service to the customer. All three of these mechanisms are interrelated and support each other to improve the effectiveness of local governance.

SAA for fiscal year 2011, nearly 50\% of districts in South Sulawesi acquire audit report of CPC is disclaimer opinion For the local budget, generally good in South Sulawesi and Southeast Sulawesi, approximately $50 \%$ of the budget for personnel expenditures absorbed, so that the budget is used for public purposes such as poverty alleviation, health and education and building community infrastructure that directly touches only a small part of the budget. Public budgets is a public policy. A policy called public policy because the policy was not already enacted, or because the policy implemented by the public, but because the content of the policy itself concerning the general welfare (Arifin and Rachbini, 2001:12). It also confirms that the level of welfare of the people affected by the decisions taken by the government through a set budget.

Budget on education and health sectors which are two very touching public services directly to the most important people met by the government (Ablo and Reinikka, 1998), but spending on education and less attention to health policy makers, so that the budget for education, health, and social, a very small percentage of the allocation in the budget (Mauro, 1998; Schiavo, 1999; Gupta et al, 2002). Based on this phenomenon, the researchers formulate the problem as follows: Is Good Governance affect the public welfare? Does Good Governance affect the public welfare through the disclosure of the Local Government Financial Statements and Audit Reports Opinion?

The results of this study are expected to provide benefits to local governments in the preparation of the budget so that the budget formulation more in the public interest to achieve the welfare of the community. For users of the financial statements of the region, particularly members of parliament, local government and communities can improve the understanding of the necessity of the financial statements and the audit of the financial statements. For regulators, central and local government, legislative and related parties (such as external auditors), the results of this research can be input in the making of regulations, systems and better mechanisms in the budgeting process as a form of accountability to the public.

\section{Literatur Review}

Good Governance The transformation of governance itself throughout the 20th century chronologically progresses through several stages, namely:

1) Stage $I$ is the era of the 20th century were marked by the consolidation of democratic governance in the Western world.

2) Stage II takes place in post-World War I, which is characterized by the strengthening of the role of government. The government began to appear dominant, which launched political regulation, economic redistribution and strong control of the political spaces in the community.

3) Stage III, the era of the 1960s and 1970s, shifting the attention of governments in Third World countries. That era is the expansion of developmental projects (modernization) conducted by the West in the Third World, which began a deepening of capitalism. At the same time deepening of capitalism was followed by a strong presence of the state and authoritarian regimes in Asia, Latin America and Africa.

4) Stage IV, entered the decade of the 1980 s, characterized by economic and financial crisis that hit the country world.

5) Stage $V$, is the era of the $1990 \mathrm{~s}$, where democratization project (which started the 1980s) are widespread. 


\section{International Journal of Science and Research (IJSR) \\ ISSN (Online): 2319-7064}

Index Copernicus Value (2013): 6.14 | Impact Factor (2014): 5.611

In this era of emerging new perspective on governance, which marked the emergence of governance and good governance. Government-centered perspective shifts to governance perspective. A number of donor agencies such as the IMF and the World Bank and international development practitioners who started to develop the idea of governance and

good covernance.http://hariyantousia.blogspot.com/2012/12/konse p-good-governance.html.

UNDP defines governance as the use of economic powers, political and administration to manage the affairs of the state at all levels. Governance covers the entire mechanism, processes, and institutions in which citizens and groups to express their interests, using the legal rights, obligations and bridging the differences between them. From the definition of governance includes three domains, namely the state (government), business (private) and the people who interact with each other. Good in the sense of good governance implies that upholds the value of people's desires, independence, and functional aspects of an effective and efficient governance. On the basis of the description, then all three domains, namely state / government, business / private sector and the public should maintain synergy in order to achieve the goal, since the three domains is a system of interdependent and inseparable.

The basic principle of the concept of good governance by UNDP include:

1. Participation. Encourage every citizen the right to use the expression in the decision making process concerning the interests of the public, either directly or indirectly.

2. Law enforcement. Realizing the enforcement of legislation that is fair to all parties without exception, upholds human rights and values in living in the community.

3. Transparency. Creates a mutual trust between the government and the public through the provision of information and ensure ease in obtaining accurate and adequate information.

4. Equality. Providing equal opportunity for every member of the community to improve their welfare.

5. Comprehension. Increasing the sensitivity of the organizers of the government against the people's aspirations without exception.

6. Insights forward. Building area based on a clear vision and strategy and engage citizens in the entire development process, so that people feel ownership and take responsibility to the progress of the region.

7. Accountability. Increase the accountability of decision makers in all areas affecting the public interest.

8. Supervision. Increasing efforts to supervise the governance and development to seek the involvement of the private and the public at large.

9. Efficiency and Effectiveness. Ensure the implementation of service to the community by using the available resources optimally and responsibly.

10. Professionalism. Improving the ability of government officials to achieve the target or targets of various policies and programs of work, to be able to provide service that is easy, fast, accurate, efficient and effective

\section{Local Government Finance Report}

Public sector organizations are required to make external financial reports. Form of public sector financial statements can basically adapted from the financial statements in the private sector that are tailored to the nature and characteristics of the public sector as well as accommodate the needs of public sector financial statements. However, the financial statements of public sector can not simply be equated with the financial statements of both the private sector and format elements. This is due to public sector organizations have restrictions in the form of non-monetary consideration, such as social and political considerations (Mardiasmo, 2002). Meanwhile, according to Bastian (2006) defines local government financial statements are: Local Government Finance Report is part of the process of financial reporting in local government is structured to present the financial position of the transactions carried out by a local government entity. From the definition, it can be concluded that the financial statements present the results of regional economic activities of an entity during a period that is intended to provide relevant information to the users of the financial statements.

According to Law 17 of 2003 on state finances, there are four basic components of the financial statements to be presented by the government:

1. Budget Realization Reports. BRR

Actual Budget report is a report which contains the information about the realization of the income, expenditure and financing of an entity that is compared with the third budget of the post. by PSAP 2 paragraph 14, Report of Actual Budget shall include at least the following items: a) income; b) shopping c) transfer; d) the surplus / deficit; e) receipt of financing; f) financing expenses; g) Net financing; h) SILPA / SIKPA.

2. Balance Sheet BS Balance of the financial position of the government regarding the assets, liabilities, and equity funds on a specific date. According to the PSAP No.01 paragraph 43, Balance Sheet include at least the following items: a) cash and cash equivalents; b) Shortterm investments; c) the tax and non-tax receivables; d) inventory; e) long-term investment; f) fixed assets; g) Short-term liabilities; h) Long-term liabilities; i) equity funds.

3. Cash Flows Statements CFS. CFS provide information about the source, use, change in cash and cash equivalents during the accounting period, and the balance of cash and cash equivalents at the reporting date. According to the PSAP No. 3, paragraph 14 is classified by operating activities, non-financial, financing, and non-budget.

4. Notes to the Financial Statements NFS. NFS include an explanation or a list or a detailed analysis of the value of an item is presented in the BRR, Balance Sheet, and the CFS. CaLK should be presented systematically. Each post in the BRR, Balance Sheet, and the CFS shall have a cross reference to the relevant information in NFS.

\section{Auditing}




\section{International Journal of Science and Research (IJSR) \\ ISSN (Online): 2319-7064}

Index Copernicus Value (2013): 6.14 | Impact Factor (2014): 5.611

The preparation of financial statements of the new government explicitly stated in Law No. 17 of 2003 on State Finance. This law is in the government's efforts to reform financial sector, given before the state's financial management using the Dutch colonial rule. The audit report, the auditor must provide an opinion on the quality or the quality of financial statements. There are five basic types of audit reports issued by the auditor (Agoes, 2004), namely:

a. Unqualified opinion. This opinion is given by the auditor if there is no limitation in the scope of the audit and there are no significant exceptions regarding fairness and generally acceptable accounting principles in the preparation of financial statements, consistency application of the accounting principles generally acceptable, and adequate disclosures in the financial statements.

b. Unqualified opinion with an explanation language (Unqulified Opinion Report with Explanatory Language). If there are things that require language explanation, however, the financial statements present fairly the financial position and results of operations of the client company.

c. Naturally, with the exception Opinion (Qualified Opinion). In the opinion of the auditor states that the financial statements presented by the client is reasonable, but there are some elements that are excluded, exclusion does not affect the fairness of the financial statements as a whole.

d. Opinions are not Fair (Adverse Opinion). This opinion is not reasonable given the circumstances the auditor aware of any impropriety client's financial statements.

e. The statement did not give an opinion (Disclaimer of Opinion). The auditor expressed no opinion because he did not obtain sufficient evidence about the fairness of the audited financial statements or because he is not independent in relation to the client.

\section{The Welfare of Society}

Welfare containing 4 meanings as proposed Midgley (2005), namely:

1. As a condition of peace (well-being). This sense the term usually refers to social welfare (social welfare) as the fulfillment of the conditions of material and nonmaterial. Prosperous condition occurs when human life safe and happy because their basic needs for nutrition, health, education, shelter, and income can be met; and when human beings gain protection from major risks that threaten their lives.

2. As social services. In the UK, Australia and New Zealand, social services generally include five forms, namely social security (social security), health care, education, housing and personal social services (personal social services).

3. As social benefits. particularly in the United States (U.S.), given to the poor. Because the majority of welfare recipients are poor people, the disabled, the unemployed, the state then cause a negative connotation to the term well-being, such as poverty, laziness, dependency.

4. As a process or a conscious effort made by individuals, social institutions, communities and government agencies to improve the quality of life (first sense) through the provision of social services (sense into two) and social benefits (the third sense).

\section{Conceptual Framework and Hypothes}

Conceptual Framework Act No. 17 of 2003 on State Finance set among other areas of financial management and accountability. These settings include the preparation of the Regional Budget performance-based and comprehensive financial reports as a form of accountability that must be examined by the Supreme Audit Agency (SAA). SAA will provide an opinion on the financial statements are examined in the form Examination Results Refort. Society has the right to know the results provided by a third party, namely the SAA so as to assess the performance of local governments, Mardiasmo (2002). This is in line with the Public Interest Theory, the information provided is part of the Good Governance. In line with the study (Taylor et al., 2008; Vu et al. 2011).

The orientation of the public sector development is intended to achieve good governance. Furthermore, UNDP has some characteristics of good governance, among others: Participation, law enforcement, Transparency, Equality, Comprehension, Insights into the future, Accountability, Oversight, the efficiency and the effectiveness and professionalism. Mardiasmo (2002). Value for money is part of the Good Governance. In the theory of decentralization / autonomy say that value for money is a bridge in achieving good governance. The description for more details we can see in Figure 1 is the conceptual framework:

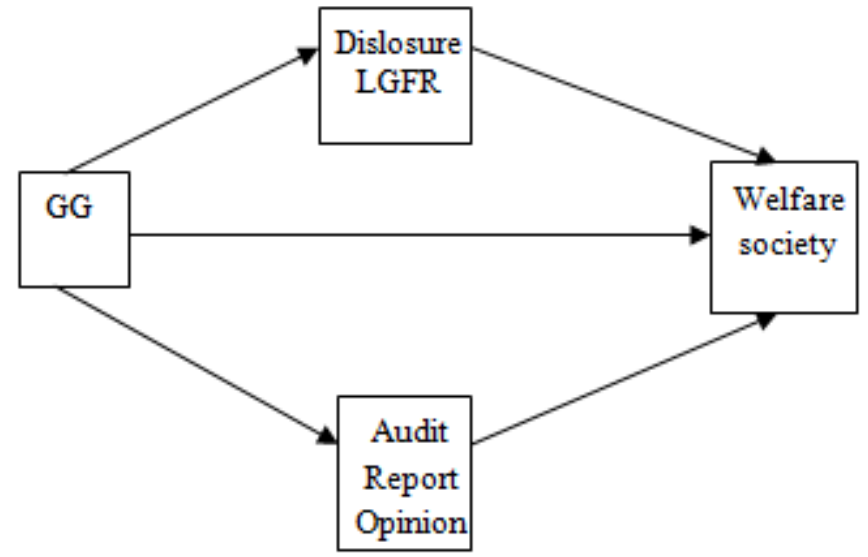

Figure 1: Conceptual Framework 


\section{International Journal of Science and Research (IJSR) \\ ISSN (Online): 2319-7064}

Index Copernicus Value (2013): 6.14 | Impact Factor (2014): 5.611

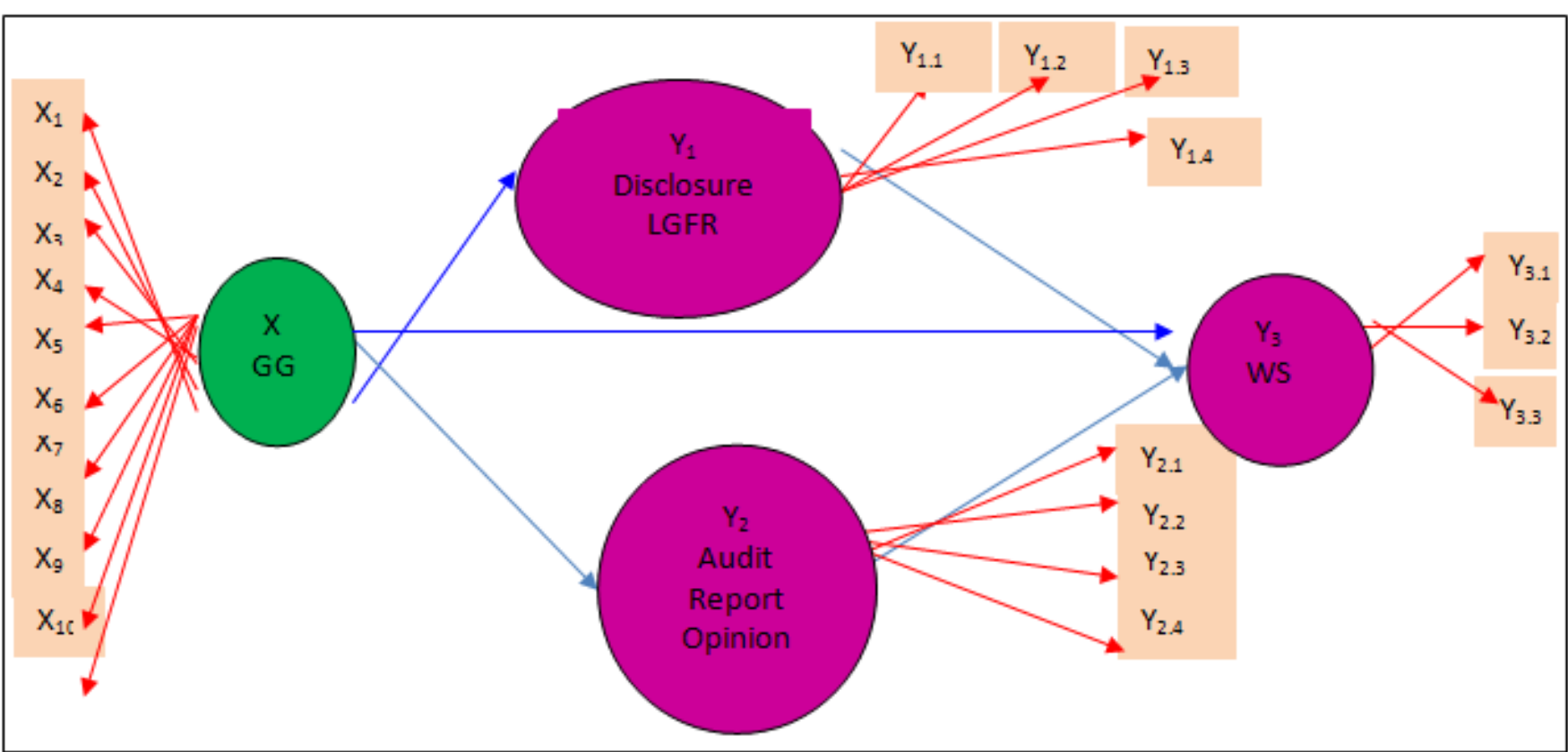

Figure 2: Empirical models

\section{Hypothesis}

Good governance are free from corruption, collusion and nepotism is something sorely missed Indonesian society. It is stated in Law No. 28 of 1999 concerning State administrators are free from corruption, collusion and nepotism. The election of new leaders is part of the will of the people who want the creation of a clean government. The expectations of the people is how they can live a more prosperous economically and politically, as stated in the Preamble of the 1945 Constitution. Economically, the people of Indonesia wants increase in per capita income, the prices of basic necessities are not expensive, reduced poverty rates, low inflation and various other indications of prosperity. Politically, the people's wishes in order to be able to walk properly democracy, respect for the rights of expression, respect for human rights, freedom to be creative and organized, and respect for freedom of others.

Research results and Ansuategi Perrings (2000), suggests that the environmental implications of deepening poverty and improve the welfare of one side on the other. Rahmanurrsyid research results (2008), concluded the implementation of accountability and transparency in local government accountability to achieve good governance obstacles because there is no evaluation of the government on accountability reports, tend to be political and public attitudes apathetic on responsibility statements.

Research Haug (2007) uses a variable public welfare as purposes variabel with HDI indicators, which concluded that the decentralization / regional autonomy has a positive effect on the welfare of the Dayak Benuag. Decentralization in Indonesia was marked by the implementation of regional autonomy. Local governments in implementing regional autonomy, required to run the government effectively and efficiently and able to support the community's role in improving equity and justice, by developing the full potential of the area to the public welfare.

\section{H1: Good Governance affect the public welfare} indicators GDP, Private Consumption and HDI

Public sector reform in Indonesia, more specifically the area of financial reform characterized by the implementation of regional autonomy and fiscal decentralization, which takes effect on January 1, 2001. Autonomous regions according to Law No. 32 of 2004, is the right of local communities to organize and manage his own household, as well as develop local potential and resources. The success of regional autonomy is inseparable from the ability of the financial sector. Able or not an area for autonomy depends on local revenue. Areas that can explore the sources of local revenue, can be independent and able to finance expenditures and to improve the welfare of society if managed properly free of corruption, collusion and nepotism.

Law No. 28 of 1999 on state officials who are free from corruption, collusion and nepotism, is the hope of the people of Indonesia. Good governance will be the public welfare as stated in Law No. 32 of 2004. In regional autonomy, local governments are required to prepare financial reports of local governments. The financial statements as a form of local government in managing local revenue along with the cash balance by Act No. 33 of 2004. Government financial statements are statements that will be made public after being reviewed by the SAA as an independent institution. This is consistent with the public interest theory. The theory is part of the public interest theory of regulation. This theory considers that regulatory guidance is the result of the public, which is the best thing in maximizing social welfare.

Rahmanurrasjid research results (2008) implementation of accountability and transparency in local government accountability to achieve good governance obstacles because there is no evaluation of the government on accountability reports, tend to be political and public attitudes apathetic responsibility statements. Widyaningsih Research (2011) informs that the financial accounting system that is effective area will improve the internal control system better. 


\section{International Journal of Science and Research (IJSR) \\ ISSN (Online): 2319-7064 \\ Index Copernicus Value (2013): 6.14 | Impact Factor (2014): 5.611}

Financial accounting system effective area supported by a good control system to produce quality financial reporting information. Pilcher (2005) found that the local government has not fully implemented accountability as recommended by the local government. The results of the study Fitr (2011) showed that the average disclosure of the information presented in the Financial Statements of Local Government pretty good, but there are no standards and rules regarding the breadth of information and account details are disclosed in FSLG.

Djuitaningsih research results (2012) concluded that the Actual Budget Report has a positive relationship to the public welfare. Research conducted by Ingram (1984), Laswad et.al. (2005), as well as Liestiani (2008) found that the area of wealth associated with the positive and significant levels of financial statement disclosure district / city government. All three of these studies have the same conclusion that the greater wealth of the area, the greater the level of disclosure made by the local government. Good financial management by applying the principles of good governance in revealing wealth and resources and the use of local revenues, will the welfare of society, so the hypothesis can be formulated as follows:

H2: Good Governance affect the public welfare indicators GDP, Public Consumption and HDI through disclosure of Local Government Finance Report.

Regional autonomy according to Law No. 32 of 2004, is a local community rights to organize and manage his own household, and to develop local potential and resources. The success of regional autonomy is inseparable from the ability of the financial sector. Able or not an area for autonomy depends on local revenue. Areas that can explore the sources of local revenue can be independent and able to finance expenditures and to improve the welfare of society if managed properly free of corruption, collusion and nepotism.

Law No. 28 of 1999 on state officials who are free from corruption, collusion and nepotism, is the hope of the people of Indonesia. Good governance will be the public welfare as stated in Law No. 32 of 2004. In regional autonomy, local governments are required to prepare financial reports of local governments. The financial statements as a form of local government in managing local revenue along with the cash balance by Act No. 33 of 2004. Article 101 of the law no. 32 explains that the local government financial reports submitted to the Audit Board no later than three (3) months after the fiscal year ends. The Supreme Audit Agency (SAA) is a state agency that holds high the constitutional mandate to inspect or audit the financial management responsibilities. SAA as a government auditor, won the trust to examine the financial statements presented by the client, namely local government. SAA provide an opinion on the financial statements on which the accountability of local government. SAA as an independent agency that does not take sides between the government and the public as users of financial statements. The public is entitled to know the results of the SAA over Mardiasmo Local Government Finance Report (2002). Test results published after approval by the board because the public is entitled to know of accountability and transparency in the management of local revanue and other funds managed by the local government. This is consistent with the public interest theory. The theory is part of the public interest theory of regulation. This theory considers that regulatory guidance is the result of the public, which is the best thing in maximizing the welfare of society.

Budhiarto research results (2011) showed that the seriousness of local governments to follow the rules of a very small effect on the financial statements so that the majority of local governments obtain disclaimer opinion. Agusriyanto research results (2010) concluded that the level of materiality positive and significant effect on the results of opinion. Hartati research results (2010) concluded that the quality of disclosures presented in the mandatory disclosure and voluntary disclosure local government financial gain unqualified opinion does not have a difference, or that there is a very significant difference.

The results of the study Hilmi (2011) found that local wealth, population and storage of test results positive effect on Local Government Finance Report. Local governments in managing and financial accountability are still many areas of disobedience, inconsistencies and management of local government assets that do not have proof. Nearly 50\% local government derive disclaimer opinion. This can result in decreased credibility of local government, both in the eyes of the people and in the eyes of investors are expected to improve the economy of the region. Thus the hypothesis can be formulated as follows:

\section{H3: Good Governance affect the welfare of society indicators GDP, Public Consumption and HDI via Opinion Audit Reports.}

\section{Methods}

\section{Population}

The population in this study are all local governments in South and Southeast Sulawesi. In South Sulawesi consists of 24 local government by eliminating the North Toraja district because it is a New Autonomous Region (NAR) and Southeast Sulawesi consists of 13 local governments in which all population census methods will be studied.

Types, Sources and Methods of Data Collection. The type of data used is the documentary that research data in the form of financial statements and performance accountability of local governments. Source data is secondary data is data obtained by researchers from existing sources and has been published to the public through the website of each local government. Data collection methods used in this study are as follows:

1. Documentation of data collection is directly related to this study.

2. Data of Public Relations Local Government Level I South and Southeast Sulawesi form:

a. Local Government Finance Report 2006-2011 year.

b. Government Performance Accountability Report 2006-2011 year

3. Data representative of the SAA South and Southeast Sulawesi a year from 2006 to 2011 Audit Reports 


\section{International Journal of Science and Research (IJSR) \\ ISSN (Online): 2319-7064 \\ Index Copernicus Value (2013): 6.14 | Impact Factor (2014): 5.611}

4. Data from Statistics South and Southeast Sulawesi form: a. Gross Domestic Product in 2005-2011.

a. Public consumption in 2005-2011.

b. HDI years 2006-2011

Research Variables and Operational Definitions To make the perception, then explained the operational definition of the study related to the study variables. Research variables with measurement indicators as explained below:

1. Good Governance. GG is the way governments manage resources for the benefit of social and economic development of a region. GG principle by UNDP includes 10 principles, namely 1) participation, public participation in decision-making process concerning the interests of the public, either directly or indirectly, in the local government that is in South and Southeast Sulawesi; 2) law enforcement, law enforcement and community fair to upholding human rights in the region South and Southeast Sulawesi; 3) transparency, South and Southeast Sulawesi local governments must provide accurate information to the public about the financial management area; 4) equality, Providing equal opportunities to every community to improve people's welfare South and Southeast Sulawesi; 5) comprehension, aspirational South and Southeast Sulawesi government to improve people's aspirations for development in order to achieve the welfare of the community; 6) foresight, South and Southeast Sulawesi Local governments and communities work together in realizing the vision and mission of regional development; 7) accountability, responsible decision makers in all areas for the benefit of society in South and Southeast Sulawesi 8) monitoring, supervision and administration of private and public development involves Sulselra; 9) the efficiency and effectiveness, use of resources and the optimal power and accountable to the public South and Southeast Sulawesi; and 10) professionalism, ability to reach the target apparatus and services easily, quickly, precisely to the public South and Southeast Sulawesi. GG was measured using an index that is by looking at the accountability of each entity, and the report identifies the principles of GG by UNDP. To measure the level of translation GG Accountability Reports Local Government Agencies to use methods that are not weighted (unweighted index / score). Examples of when an entity describes only 7 then: $(7 / 10) * 100 \%=70 \%$ as research (Taylor at el. 2008).

2. Disclosure of Local Government Finance Report. Disclosure is how local governments reveal the wealth, the source and use of funds to a local government that is listed in the Local Government Finance Report. LGFR disclosure can be measured by the percentage of disclosure. There are two (2) methods used to measure the level of disclosure. The first method uses an index that is not weighted (unweighted index) or using a dichotomous Score. In this method of disclosure index calculation is done by giving a value of 1 for the items disclosed, while 0 for items that are not disclosed in accordance with the disclosure of a list of items made by the researcher. The second method is to use the scheme or the weighted index (weighted scheme / index) which is based on a subjective assessment analysts and financial statement users surveyed over certain items anual report that is sorted in order of priority. The level of disclosure is measured by comparing the items disclosed in the financial statements produced by the local government with the items that must be disclosed in the financial statements of local governments with reference to the Government Regulation No.24 of 2005 regarding the Government Accounting Standards. The level of disclosure is measured by identifying what information is presented on the items disclosed in the Financial Statements of Local Government. To measure the level of disclosure of the method used depth information that is not weighted (unweighted index / score). In the measurement of disclosure index, the information disclosed in LGFR compared with the information disclosed by the Government Accounting Standards in appendix 2. For items that are disclosed in accordance with the disclosure of the GAS will be given a value of 1 , whereas for an undisclosed items were given a value of 0 . disclosure index is the total number of items disclosed divided by the maximum number of disclosures. information disclosed in the financial statements, respectively, by summing the items disclosed in the individual reports divided by the items that should be disclosed in each report. For example, items that are disclosed in the Balance of State X is 17 items, while the disclosure of the balance sheet total is 43 items, the disclosure of which is the percentage $(17 / 43) * 100 \%=40 \%$ ) (Taylor et al. 2008).

3. Opinion Audit Reports. Opinion Audit Reports is the opinion given by the independent auditor LKPD disclosures compiled by the local government as budget management accountability. Local governments are acquiring opinions can be seen the percentage deviations to obtain the opinion. To gauge the opinion, the researcher makes the index is 1-5. If governments derive Adverse opinion then it would be 3, as compared with the existing opinions based on the theory that there are as many opinions 5 . So $(3 / 5 * 100=60 \%)$. Results The percentage indicates the percentage of irregularities committed by the government, such as the study (Taylor et al. 2008).

4. Welfare society. Welfare of the community if the community is able to meet the physical and spiritual needs, security and justice. Public welfare is measured using GDP per capita, education levels and life expectancy, the data is taken from BPS South and Southeast Sulawesi.

\section{Data analysis}

To ascertain whether there is influence between GG against LGFR Disclosure, Audit Report, and Public Welfare, the test is done with test Path Analysis, using Partial Least Squre program (PLS). Used path analysis with the consideration that the pattern of relationships between variables in the study is correlative nature. Testing mediating variables referring to Baron and Kenny (1986), which states that in order to determine a variable as a mediating variable, it must meet the following conditions.

1) Variables beginning (initial variable) correlated with the outcome variable.

2) Initial variable is correlated with the mediating variable. 


\section{International Journal of Science and Research (IJSR) \\ ISSN (Online): 2319-7064 \\ Index Copernicus Value (2013): 6.14 | Impact Factor (2014): 5.611}

3) Mediating variables affect the outcome variable.

4) To establish that the mediating variable fully mediates the initial variable relationship with the outcome variable, the effect of the initial variable on the outcome variable by controlling the mediating variables must be zero. If these four steps are met, it can be concluded that the mediating variable fully mediates the relationship variables beginning with variable results. If the first three steps but step 4 is not met, then this indicates a partial mediation.

To see GG to variable Disclosure FSLG and Audit Report Opinion as a mediating variable and the welfare of society as the outcome variables tested using the data of +1 and +2 years of data for each variable and the mediating variable purposes. This is done as a follow-up of the relationship will appear in the next one or two years. To see the effect of GG on the indicators that make up the community variable then tested welfare indicators in order to see the influence of each indicator variable which measures the well-being of society.

\section{Results}

\section{Description of Research Results}

Analysis description of variables, this study aims to interpret the meaning of each study variable, the indicator variable is based on the average (mean) of the study data. The variables analyzed are: good governance (X); local government financial statements (Y1); examination report (Y2); and welfare of the people (Y3). The results of a survey conducted in 37 local government there is one area that can not be included in the sample because the area has a negative value and there are also some areas that samples only a few years because its value is also negative, so the data is considered as a sample of only 170 of the 228 samples.

\section{Variable Description Good Governance}

Good Governance in this study focused on how governments manage resources for the benefit of social and economic development of a region. GG indicators are indicators issued by (UNDP). Because the indicator used to reflect GGG constructs consisting of ten indicators, namely: X1. participation; X2. Law enforcement; X3. transparency; X4. equality; X5. Comprehension; X6. Insights into the front; X7. accountability; X8. supervision; X9. The efficiency and effectiveness; and X10. Professionalism.

Based on the panel data mean GG with ten indicator variables of the 37 local governments in the period of 6 years was 0.84 . Variable GG small implements occurred in 2006 at 0.70 . And the highest in the years 2010-2011 amounted to 0.99 . While most small local governments mean applying the ten indicators GG is Muna regional governments and most major indicators apply GG is Bantaeng government. This means that local government has outlined South and Southeast Sulawesi; GG with a mean 8 indicators, namely participation, rule of law, transparency, equality, perception, foresight, accountability, the efficiency and effectiveness.
Description of Variables Local Government Financial Statements How LGFR disclosure reveals a wealth of local government, the sources and uses of funds at a local government that is listed in the Local Government Finance Report. Indicator variable LGFR disclosure under Regulation No. 24 of 2004 is Balance $\left(Y_{1.1}\right)$, Actual Budget Report $\left(\mathrm{Y}_{1.2}\right)$, Statement of Cash Flow $\left(\mathrm{Y}_{1.3}\right)$ and Notes to the Financial Statements $\left(\mathrm{Y}_{1.4}\right)$. This indicator avarate giving rise to a number of variables LGFR disclosure. When tested by the panel data disclosure LGFR average variable with four indicators of the 37 local governments in the period of 6 years was 0.73. Variable revealing small LGFR revealed LGFR is Bulukumba governments of 0.62, while most big reveal LGFR Konawe government and Bau-Bau of 0.85 . This means that local governments Sulselra LGFR disclosure for a period of 6 years was nearing the disclosures set out in the Government Accounting Standards by Government Regulation 71 of 2007.

\section{Variable description Audit Reports Opinion}

Audit Reports Opinion are given by the independent auditor LGFR disclosures compiled by the local government as budget management accountability. Audit report indicator variables based on SAA are unqualified Opinion $\left(\mathrm{Y}_{2.1}\right)$, Qualified opinion $\left(\mathrm{Y}_{2.2}\right)$, adverse opinion $\left(\mathrm{Y}_{2.3}\right)$ and disclaimer opinion $\left(\mathrm{Y}_{2.4}\right)$. When tested by the panel data variables audit report mean deviation of 37 local governments in a period of 6 years at 12:54. This means that the average government opinions adverse opinion gain. Favorable opinion occurred in 2006 with the amount of deviation of 0.4 means the majority of local governments obtain qualified opinion. Years 2007-2011 the mean deviation of $0.5-0.6$. meaning that the majority of local governments acquire Advers opinion. While most governments averaged less gain disclaimer opinion with the amount of deviation of 0.8 or close to the mean is the government Maros, Jeneponto, Selayar, Konawe, South Konawe, North Konawe, and North Buton and most well say that qualified opinion of $0.4-0.5$ is Makassar city government, town of Pare-Pare, Pinrang, Sidrap, Wajo, Palopo city, Takalar, Bantaeng, Sinjai, Bone, Enrekang, Southeast Sulawesi; , the city of Kendari, Buton, dan Muna .

\section{Variable Description The Welfare of Society}

The welfare of Society achieved if the community can meet the physical and spiritual needs, security and justice. The welfare of society indicators which GDP $\left(\mathrm{Y}_{3.1}\right)$, Public Consumption $\left(\mathrm{Y}_{3.2}\right)$, and HDI $\left(\mathrm{Y}_{3.3}\right)$. This indicator is used to reflect the construct of Public Welfare.

GDP indicator When tested by the panel data with a mean of Welfare of society indicator variable GDP of 37 local governments in a period of 6 years at 12:08. GDP is the lowest of the period of 6 years ie in 2007 of 00:05. And the highest occurred in 2008, 2009 and 2011 is 0:08. The smallest local government mean that government Jeneponto, Enrekang, Kolaka, and the city of Bau-Bau is equal to 0.05 GDP, and most large Wakatobi government of 0:15 followed by 0:14 local government and the local government of Southeast Sulawesi North Buton at 0.12. This means that local governments in South and Southeast Sulawesi; GDP per capita economic growth rate during the 6 years only amounted to $8 \%$. This suggests that the added value that can 


\section{International Journal of Science and Research (IJSR) \\ ISSN (Online): 2319-7064 \\ Index Copernicus Value (2013): 6.14 | Impact Factor (2014): 5.611}

be created by the residents due to the very small production. It indicated the difficulty of the population earn extra income or unemployment that occurred in South and Southeast Sulawesi.

\section{Public Consumption Indicator}

When tested by the panel data mean welfare society with an indicator variable consumption of 37 local governments in the period of 6 years at 12:55. lowest consumption of a period of 6 years ie 2006-2010 by 0:55. And the highest occurred in 2011 at 0:26. Mean the smallest local government consumption is at 0:53. Southeast Sulawesi; government, local governments and most large East Luwu by $0: 58$. This means that local governments in South and Southeast Sulawesi; consumption above $50 \%$, which is the result of individual consumption society. This indicates that the community can meet the needs of material South and Southeast Sulawesi; without government interference.

Indicators of Human Development Index When tested by the panel data mean welfare society with an indicator variable
HDI of 37 local governments in a period of 6 years was 0.70 . HDI within a period of 6 years from 2006 to 2011 is unchanged at $0.69-0.71$. The smallest local government mean that government Jeneponto HDI 0.64 and the greatest local governments amounted to 0.78 Makassar, Pare-Pare then city of 0.77 , followed by 0.76 Palopo city, city of Kendari 0.75. Further North Luwu at 0.74, followed by government Luwu, Enrekang and Bau-Bau of 0.73. This means that local governments in South and Southeast Sulawesi; HDI are in medium condition. This indicates that human development has improved. The improvement in human development depends on the commitment of local governments to increase the capacity of the base population impact on improving the quality of life.

\section{Direct Influence}

The test results direct influence between variables can be seen in full in Table 1 below:

Table 1: Coefficient of Direct Line Influence

\begin{tabular}{|c|c|c|c|c|c|c|c|c|c|c|}
\hline \multirow[t]{2}{*}{$\mathrm{Hpt}$} & & \multicolumn{3}{|c|}{$\mathrm{Y}_{\mathrm{t} 0}$} & \multicolumn{3}{|c|}{$Y_{t+1}$} & \multicolumn{3}{|c|}{$\mathrm{Y}_{\mathrm{t}+2}$} \\
\hline & & Coef. & T static & & Coef. & T static & & Coef. & T static & \\
\hline & GG $(\mathrm{X})->$ FSLG $\left(\mathrm{Y}_{1}\right)$ & -0.017 & 0.1624 & ns & 0.0613 & 0.5753 & ns & 0.0736 & 0.6558 & ns \\
\hline & GG $(\mathrm{X})->\mathrm{AR}\left(\mathrm{Y}_{2}\right)$ & 0.0124 & 0.1121 & ns & -0.055 & 0.4663 & ns & -0.236 & 2.3721 & $\mathrm{~s}$ \\
\hline & GG $(\mathrm{X})->\operatorname{GDP}\left(\mathrm{Y}_{3,1}\right)$ & -0.009 & 0.0559 & ns & 0.0683 & 0.6217 & $\mathrm{~ns}$ & -0.04 & 0.3172 & $\mathrm{~ns}$ \\
\hline & $\mathrm{GG}(\mathrm{X})->\mathrm{PC}\left(\mathrm{Y}_{3}\right)$ & 0.008 & 0.0814 & ns & 0.0683 & 0.6217 & ns & 0.3304 & 2.9905 & $\mathrm{~S}$ \\
\hline & GG $(\mathrm{X})->$ HDI $\left(\mathrm{Y}_{3.3}\right)$ & 0.3208 & 3.1538 & $\mathrm{~S}$ & 0.1229 & 1.0587 & $\mathrm{~ns}$ & 0.0674 & 1.8011 & $\mathrm{~S}$ \\
\hline & FSLG (Y1) -> GDP(Y $\left.{ }_{3.1}\right)$ & -0.134 & 1.2159 & ns & -0.1542 & 1.9359 & sig. & -0.194 & 2.3823 & $\mathrm{~S}$ \\
\hline & FSLG (Y1) -> PC $\left(\mathrm{Y}_{3.2}\right)$ & -0.053 & 0.4663 & ns & -0.055 & 0.4345 & ns & -0.029 & 0.2514 & Ns \\
\hline & FSLG (Y1) -> HDI $\left(Y_{3.3}\right)$ & -0.067 & 0.7519 & ns & -0.042 & 0.4799 & ns & -0.114 & 1.1962 & Ns \\
\hline & $\operatorname{AR}(Y 2)->\operatorname{GDP}\left(\mathrm{Y}_{3.1}\right)$ & 0.1297 & 1.1973 & $\mathrm{~ns}$ & 0.1009 & 0.999 & $\mathrm{~ns}$ & 0.1406 & 1.6936 & $\mathrm{~S}$ \\
\hline & AR (Y2) -> PC $\left(\mathrm{Y}_{3.2}\right)$ & -0.047 & 0.4638 & ns & -0.0057 & 0.0578 & ns & 0.0654 & 0.6056 & Ns \\
\hline & $\mathrm{AR}(\mathrm{Y} 2)->\mathrm{HDI}\left(\mathrm{Y}_{3.3}\right)$ & -0.215 & 2.6136 & $\mathrm{~S}$ & -0.2071 & 2.2999 & $\mathrm{~S}$ & -0.267 & 2.7255 & $\mathrm{~S}$ \\
\hline
\end{tabular}

The results of the analysis of the data in Table 1 it can be seen that in $\mathrm{Y}_{\mathrm{t} 0}$ significant direct effect, there are only 5 significant and proven hypothesis $\mathrm{H} 1$ only. In $\mathrm{Y}_{\mathrm{t}+1}$ there is a significant direct effect of 6 and no hypothesis is accepted. In $\mathrm{Y}_{\mathrm{t}+2}$ there are 10 significant direct effect and hypothesis $\mathrm{H} 1$ is accepted. Based on the test results the further discussion to directly influence the test results will be discussed with $\mathrm{Y}_{\mathrm{t}+2}$.

\section{Indirect Influence}

Testing the indirect effect (mediation) aims to detect the position of intervening variables in the model. Mediation testing was conducted to determine the nature of the relationship between both variables as a mediating variable perfect (complete mediation), mediation part (partial mediation) and not a mediating variable. Testing the effect of indirect or mediating variable in this study was conducted with four stages, as follows: (1) examine the direct effect of variable $\mathrm{X}$ (initial variable) to variable $\mathrm{Y}$ (the outcome variable); (2) examine the direct effect of variable $\mathrm{X}$ to variable Y (mediation); (3) examine the influence of mediating variables to variable Y; (4) examine the effect of variable $\mathrm{X}$ to variable $\mathrm{Y}$ after inserting a mediating variable will have no effect. If these four steps are met, it can be concluded that the mediating variable fully mediates the relationship variables beginning with variable results. If the first three steps but step 4 is not met, then this indicates a partial mediation (Barron and Kenny, 1986).

Based on the test results of the indirect effect using $Y_{t 0}, Y_{t+1}$ and $\mathrm{Y}_{\mathrm{t}+2}$, we can see in table 2 below:

Table 2: Testing Variables Mediation $\mathrm{Y}_{\mathrm{t} 0}, \mathrm{Y}_{\mathrm{t}+1}$ and $\mathrm{Y}_{\mathrm{t}+2}$

\begin{tabular}{|c|c|c|c|c|c|c|c|}
\hline \multirow[t]{2}{*}{ Hpt } & & \multicolumn{2}{|c|}{$\mathbf{Y}_{\mathrm{t} 0}$} & \multicolumn{2}{|c|}{$\mathbf{Y}_{t+1}$} & \multicolumn{2}{|c|}{$\mathbf{Y}_{\mathrm{t}+2}$} \\
\hline & & Coef. & & Coef. & & Coef. & \\
\hline \multirow{3}{*}{2} & GG(X) ->FSLG(Y1)-> GDP (Y3.1) & 0.0023 & $\mathrm{~nm}$ & -0.0095 & $\mathrm{~nm}$ & -0.0143 & $\mathrm{~nm}$ \\
\hline & GG(X) ->FSLG(Y1)-> PC (Y3.2) & 0.0009 & $\mathrm{~nm}$ & 0.0034 & $\mathrm{~nm}$ & -0.0021 & $\mathrm{~nm}$ \\
\hline & GG(X) ->FSLG(Y1)-> HDI (Y3.3) & 0.0011 & $\mathrm{~nm}$ & -0.0026 & $\mathrm{~nm}$ & -0.0084 & $\mathrm{~nm}$ \\
\hline \multirow{3}{*}{3} & GG(X) ->AR(Y2)-> GDP (Y3.1) & 0.0016 & $\mathrm{~nm}$ & -0.0056 & $\mathrm{~nm}$ & -0.0331 & $\mathrm{~nm}$ \\
\hline & GG(X) ->AR(Y2)-> PC (Y3.2) & -0.0006 & $\mathrm{~nm}$ & 0.0003 & $\mathrm{~nm}$ & -0.0154 & $\mathrm{fm}$ \\
\hline & GG(X) ->AR(Y2)-> HDI (Y3.3) & -0.0027 & $\mathrm{~nm}$ & 0.0114 & $\mathrm{~nm}$ & 0.0628 & $\mathrm{pm}$ \\
\hline
\end{tabular}




\section{International Journal of Science and Research (IJSR) \\ ISSN (Online): 2319-7064}

Index Copernicus Value (2013): 6.14 | Impact Factor (2014): 5.611

Based on Table 2, it can be seen that the indirect effect for Yt0 no mediation. This means that in the GG variables directly affect the well-being of people with HDI indicator and does not affect the mediating variables, namely FSLG disclosure and Audit Report Opinion LKPD. Indirect effect by $Y_{t+1}$, mediation hypothesis is not even proven. Indirect effect by $\mathrm{Y}_{\mathrm{t}+2}$, only one hypothesis is rejected, namely $\mathrm{H} 2$ where GG had no effect on the welfare of society through FSLG disclosure. Based on test results, showed that the implementation of the new GG could have an impact after 2 years of running for local government in South and Southeast Sulawesi. The test results mediating variables can be seen in full in Table 3 below:

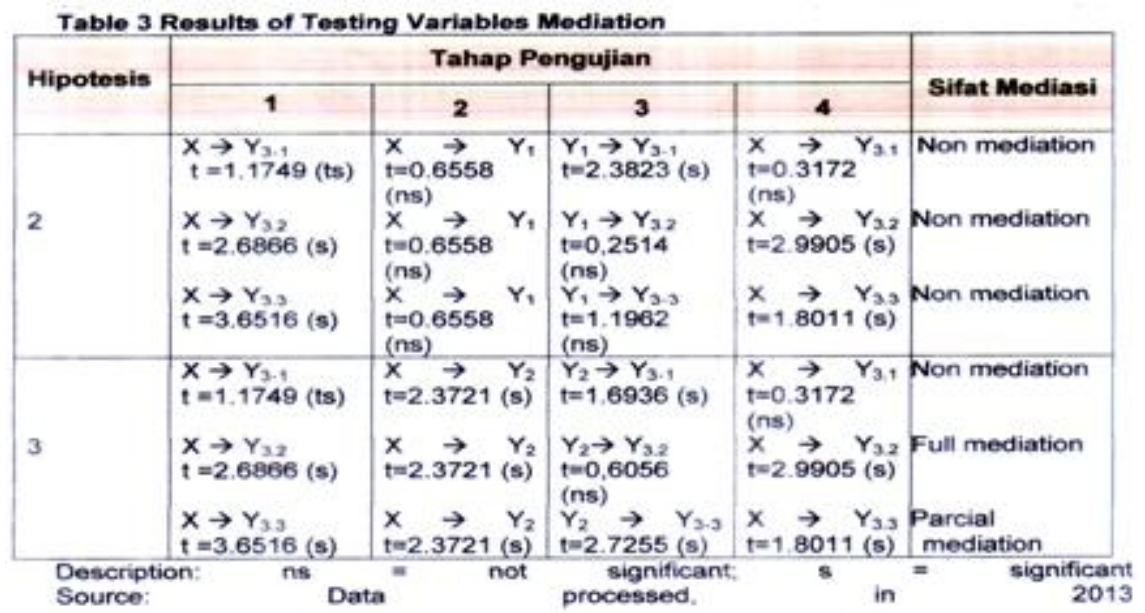

Based on Table 3, we can see the value of the path coefficient. From the method of comparison of coefficients and path coefficients significance test is the indirect effect (mediation), as follows:

1) Effect of Good Governance of the Welfare of society through Disclosure FSLG. The evaluation results of testing the effect of good governance for the welfare of society through disclosure FSLG as mediating variables, variables indirect effect on the welfare of society through the GG, disclosure FSLG indicates that no mediation. Hypothesis is rejected. This means that in assessing accountability in the assessment conducted by the Ministry of State Apparatus, disclosure FSLG not be one indicator of assessment, so that proves the hypothesis is rejected.

2) Effect of Good Governance Through Welfare of society Audit Report Opinion. The evaluation results of testing the effect of good governance for the welfare of society through Audit Report Opinion (ARO) as a mediating variable, that variable GG indirect effect on the welfare of the community through Audit Report Opinion GDP indicator showed that no mediation. Indirect effect on the welfare of society GG variable indicator of public consumption through ARO suggests that the full mediation. It shows that the ARO does not affect the consumption indicator, so that said full mediation. GG to the public welfare through the HDI indicators ARO suggests that partial mediation. It shows that there effect of the third variables suggesting partial mediation. There is the influence of good governance to the welfare of society consumption and HDI indicators (H1 accepted). So statistically GG does not affect the welfare of the community with the GDP indicator.

Based on the results of the analysis using PLS demonstrated that there is influence between the good governance of the welfare of Society with consumption indicator. This is evidenced by the value of 0.3304 coefisien lines the 0.05 level. GG then statistically affect the welfare of society with consumption indicator. Based on the results of the analysis using PLS demonstrated that there is a significant relationship between good governance of the welfare of Society with HDI indicators. This is evidenced by the value of 0.0674 coefisien lines the 0.05 level. GG then statistically affect the welfare of the community with the HDI indicators. The results of this study are supported by research Haug (2007) who found a positive effect on welfare Decentralization Dayak Benuag.

Proved that there is no influence between Good Governance with the Welfare of society through disclosure FSLG. Hypothesis (H2) is rejected. It is statistically proven by referring to Barron and Kenny (1986) Effect of GG against the welfare of society indicators GDP, public consumption and HDI through disclosure FSLG is not mediation. Thus the hypothesis $(\mathrm{H} 2)$ is rejected. This means that the relationship between GG directly or indirectly affect the public welfare indicators GDP, private consumption and HDI through disclosure FSLG.

The results of this research is, GG does not affect the public welfare through disclosure FSLG. That is disclosure FSLG is not a mediating variable between the GG with the welfare of society. But disclosure FSLG is a concept that becomes an independent variable such as Mack's research and Ryan (2011), and became a dependent variable such as research and Oktafani Djuitaningsih (2012).

Proved that there is influence between Good Governance with the Welfare of society through ARO. It is statistically proven by referring to Barron and Kenny (1986) with the results of full mediation and partial mediation. GG no effect on the welfare of society by inidicator of GDP through ARO. This means that the relationship between GG directly or indirectly affect the welfare of society with public consumption and HDI indicators through ARO. 


\section{International Journal of Science and Research (IJSR)}

ISSN (Online): 2319-7064

Index Copernicus Value (2013): 6.14 | Impact Factor (2014): 5.611

\section{Conclusions, Implications and Recommendations}

The results of this study can be summarized as follows: Good Governance effect through the welfare of society on consumption and HDI indicators; Good governance does not affect the welfare of society through disclosure FSLG; and Good Governance affect the public welfare with public consumption and HDI indicators through Audit Report Opinion. Good Governance has no effect on the welfare of GDP indicator society through Audit Report Opinion.

\section{Implications}

The implications of these results are discussed below:

1) Results of this study support the research that saw a significant relationship between Good Governance with the welfare of society. Perrings and Ansuategi (2000), Awio and Northcott (2001), Haug (2007), Rahmanurrasyid (2008), who found that decentralization positive and significant effect on welfare. In addition, this study proves that there is a direct relationship between the GG with the public welfare through public consumption indicators and HDI.

2) Results of this study found that the disclosure FSLG variables in this model is not an intervening variable (mediation), because it proved that there was no statistically significant relationship between GG with the welfare of society. It is indicated that GG has not been implemented in the real / concrete because it is not supported by adequate infrastructure, for example in terms of human resources, telecommunications facilities, electricity, mainly in the new autonomous region in North Konawe, strategic industries, which is in the province South Konawe Southeast Sulawesi. By him that the results of this study can serve as an input for local governments in the preparation of the budget that is more in the public interest to achieve the welfare of society.

3) Results of this study can be a mirror for the executive and the legislature in order musrembang that has been done can be accommodated as an aspiration of the people according to their needs, so that equity and welfare society can be realized in accordance with the vision of local government in South and Southeast Sulawesi.

\section{Limitations of Research}

Researchers are not separate South Sulawesi and Southeast Sulawesi because no research done in fact a gap between Sulawesi and Southeast Sulawesi. But on the financial management of the province which can be tested most obedient and obey the rules or the Government Internal Control System.

\section{Suggestions}

Based on the conclusions that have been presented previously, the researcher can suggest the following:

1) South and Southeast Sulawesi local government in maintaining or even improving the HDI (life expectancy, literacy, education and standard of living) that the successor generation (HR) higher quality, so that the welfare of the people who became the vision of local government in particular and the State in general purpose can be achieved .

2) Suggested to the government that any use of the budget must be accounted for in order to create a good financial governance, and better employee / employees handling financial governance in accordance with the disciplines, so that the quality of the financial statements can be met.

3) Expected that the local government in order to arrange South and Southeast Sulawesi good financial administration. Recommendations made by the SAA should be followed, so that shortcomings and weaknesses were found in the Audit Report can be repaired and equipped so FSLG can get a better. Local governments in South and Southeast Sulawesi race to achieve the highest Unqualified opinion, because local governments predicate Unqualified Opinion will get the reward of Ministry of internal Affairs

4) Suggested to the researchers who want to continue this study in order to test the performance of local government as a variable contingencies. Is local government performance variables can speed up or slow down the welfare of society.

\section{References}

[1] Ablo, Emmanuel and Ritva Reinikka. , 1998. Do budgets really matter? Evidence from public spending on education and health care in Uganda. World Bank. Policy Research Paper 1926.

[2] Agoes Sukrisno . 2004. Auditing Issue 3. Jakarta: Indonesian Economic Faculty Hall Publishers.

[3] Agusriyanto Toro. 2010. Materiality level of the CPC examination of financial statements of local governments in 2006. Journal Guna Dharma University, Jakarta.

[4] Amiruddin Zul Hilmi and Martani Dwi. 2011. Analysis of the factors that influence the level of disclosure of Local Government Finance Report. Accounting to the XIV National Symposium. Purwokerto.

[5] Arifin, Bustanul and Educate J.Rachbini. 2001. Political Economy and Public Policy. Jakarta: PT Grasindo.

[6] Baron, R.M, and D.A. Kenny. 1986. "Mediation The Moderator-Variable Distinction in Social Psychological Research: Conceptual, Strategic and Statistical Considerations." Journal of Personality and Social Psychology, 51, 1173-1182.

[7] Bastian, Indra. 2006. Accounting An Introduction to the public sector. Publisher. Jakarta

[8] Budiartha Ketut. 2011. Tracing the independent auditor opinion LKPD Bali Province. Journal of Accounting. Faculty of Economics, University of Udayana, Bali.

[9] Charles Perrings, Ansuategi Alberto. 2000. Sustainability of growth and development. Journal of Economic Studies. Vol. 27 Iss: 1 pp.. 19-54.

[10]Djuitaningsih Tita, Maulida Oktafani. 2012. Relations PSAP Application No. 2 on the budget realization report Welfare Society (Case studies on local government of South Tangerang). National Symposium on Accounting XV in Banjarmasin. sping-Andersen, G. 2002. Why We Need a New Welfare State. Oxford University Press, Oxford.

\section{Volume 5 Issue 2, February 2016}




\section{International Journal of Science and Research (IJSR) \\ ISSN (Online): 2319-7064}

Index Copernicus Value (2013): 6.14 | Impact Factor (2014): 5.611

[11] Esping-Andersen, G. 2002. Why We Need a New Welfare State. Oxford University Press, Oxford.

[12] Fitri, Sri Adella. , 2011. Financial Statements Analysis of Local Government. Thesis. Gajah Mada University, Yogyakarta.

[13] Government Regulation No. 60 of 2007 on the Financial Statements.

[14] Government Regulation No. 8 of 2006 on Financial Reporting and Performance of Government Agencies.

[15] Grantley Taylor, Greg Tower, Mitchell Van Der Zahn, John Neilson. , 2008. Corporate governance determinants on Australian resource companies financial instrument disclosure practices. Asian Review of Accounting. Vol. 16.

[16]Gupta, Sanjeev, Hamid Davoodi, and Erwin R. Tiongson. 2002. Corruption and the provision of health care and education services, in Abed, George T, and Sanjeev Gupta (eds). 2002. Governance, Corruption, and Economic Performance. Washington, D.C. International Monetary Fund.

[17] Hardjasoemantri Koesnadi. , 2003. Good Governance in Sustainable Development in Indonesia. For a paper to the National Law Development Workshop VIII in Bali.

[18] Hartati Yenni. 2010. Analysis of Financial Statements Unqualified Opinion (Study Padang Pariaman and Pariaman. Article.

[19] Haug, Michaela. , 2007. Poverty and Decentralization in West Kutai: Impact of Regional Autonomy on Welfare Benuaq. Research Report. Bogor, Indonesia: Center for International Forestry Research (CIFOR).

[20] Hilmi Amiruddin Zul dan Martani Dwi. 2011. Analisys of the factors affecting the level of local government financial statement disclosure. Accounting National Symposium to $X I V$. Purwokerto.

[21] http://hariyantousia.blogspot.com/2012/12/konsepgood-governance.html

[22] IAI. 2010. Financial Accounting Standards

[23] Ingram, Robert W. 1984. Economics Incentives and the Choice of State Government Accounting Practices. Journal of Accounting Research. Vol. 22. No. 1. Pp. 126-144.

[24] Janet Mack, Christine Ryan. 2006. Reflections on the theoretical underpinnings of the general-purpose financial reports of Australian government departments. Accounting, Auditing \& Accountability Journal. Vol. 19 Iss: 4 pp. 592-612.

[25] Krina, Lalolo. $P$ "the indicators and measures of accountability, transparency and participation" Http/good governance: Bappenas.go.id. / Informasi.Htm, Secretary Good Public Governance. National Development Planning Agency.

[26] Laswad, Fawzi, Fisher, Richard, and Oyelere, Peter. 2005. Determinants of Voluntary Internet Financial Reporting by Local Government Authorities. Journal of Accounting and Public Policy 24. Pp. 101-121.

[27] Law No. 11 Year 2009 on Social Welfare.

[28] Law No. 15 of 2006 regarding the BPK.

[29] Law No. 17 of 2003 on State Finance set among other areas of financial management and accountability.

[30] Law No. 32 Year 2004 on Regional Government.

[31] Law No. 33 Year 2004 on National and Local Balance. Constitution of the Republic of Indonesia Year 1945.
[32] Law No. 28 of 1999 on state officials who are free from corruption, collusion and nepotism.

[33] Liestiani, Annisa. 2008. Disclosure LKPD Regency / City in Indonesia for Fiscal Year 2006. Journal. UI. Depok.

[34] Mardiasmo. ， 2001. Supervision, Control, and Performance Examination of Government in Regional Autonomy, Journal of Business and Accountancy, School of Economics, Trisakti. Jakarta, August issue.

[35] Mardiasmo. 2002. Elaboration Public Sector Accounting Reform: Critical Review of the effort Actualization Needs Local Government Financial Accounting System. Indonesian Journal of Accounting and Auditing. FE UII Yogyakarta. Vol. No. 6. 1. June. pp. 63-82.

[36] Mardiasmo. 2003. Challenges in the Public Sector Accounting Achieve Good Governance in the Perspective of Regional Autonomy and Fiscal Decentralization Towards a New Indonesia. National Seminar Papers Indonesian Accountants Association of South Sulawesi.

[37] Mardiasmo. 2004. Flowers Potpourri: Autonomy and Financial Management. Andi, Yogyakarta.

[38] Mauro, Paolo. , 1998. Corruption and the composition of government expenditure. Journal of Public Economics 69: 263-279.

[39] Midgley, James. 2005. Social Development; Development Perspective in Social Welfare. MORA Deperta Indonesia, Jakarta.

[40] Performance Management. Vol. 54 Iss: 5 pp. 451-467

[41]Permenpan No. 29 Year 2010 on Guidelines for Preparation of Determination Performance Accountability and Reporting Performance of Government Agencies.

[42] Rahmanurrasjid Amin. , 2008. Accountability and transparency in local government accountability for ensuring good governance in the Region Kebumen district. Thesis. Diponegoro University, Semarang

[43] Regulation of the Minister Affairs Number 13 Year 2006 on Guidelines for Financial Management.

[44] Regulation of the Minister Affairs Number 59 Year 2007 on Amendment

[45] Robyn Pilcher. 2005. Local government financial key performance indicators - not so relevant, reliable and accountable. International Journal of Productivity and Schiavo. Campo, Salvatore (Editor). 1999. Governance, Corruption, and Public Management. Manila: Asian Development Bank.

[46] UNDP, World Bank, ADB. 2000. Partnership to Support Government Reform in Indonesia.

[47] Vu Anh Kelly, Greg Tower, Scully Glennda. 2011. Corporate communication for Vietnamese listed firms. Asian Review of Accounting. Vol. 19 Iss: 2 pp. 125146.

[48] Widyaningsih Aristanti, Triantoro Alvarez, Lili Wiyantoro Sugeng. 2011. Relations effectiveness of financial accounting and internal control area with quality financial accountability: The quality of financial reporting information as an intervening variable. Accounting to the XIV National Symposium in Aceh. 